\title{
Efficacy of fructooligosaccharide versus placebo for treatment of acute diarrhea in children: A double-blind randomized clinical trial
}

\author{
Reni Suryanty, MD; Supriatmo, MD; Berlian Hasibuan, MD; Atan Baas Sinuhaji, MD
}

\begin{abstract}
Objective To compare the efficacy of fructooligosaccharide (FOS) versus placebo in pediatric patients with acute diarrhea with regard to duration and frequency of diarrhea and the volume and consistency of the stools.

Methods This double-blind randomized clinical trial was carried out from July to November 2003 in the pediatric intensive care unit, outpatient clinic, and pediatric ward of Adam Malik Hospital and Pirngadi Hospital, Medan. Subjects were children and infants aged 4 to 24 months suffering from acute diarrhea without dehydration or with mild to moderate dehydration whose parents gave consent. Children included in this trial received tablets of either $600 \mathrm{mg}$ FOS or $761 \mathrm{mg}$ fructulin as placebo. Patients with mild to moderate dehydration were initially rehydrated according to the WHO protocol. Afterwards, 10 tablets of FOS or placebo were given to each subject to be taken twice daily. In subjects without dehydration, the tablets were given by their parents. Daily follow-up was performed, in which body weight, temperature, duration and frequency of diarrhea, and the volume and consistency of stools were recorded. For outpatients, home visits were made.

Results Out of 142 children who met inclusion criteria, $135 \mathrm{com}$ pleted the study. These consisted of 68 children in the FOS group and 67 in the placebo group. Subjects were mostly $<12$ months of age $(57.0 \%)$, male $(57.8 \%)$, and moderately malnourished (34.1\%). There was no statistically significant difference between both groups in the duration and frequency of diarrhea and the volume and consistency of stools $(P>0.05)$.

Conclusion There is no effect of the administration of FOS as supplemental therapy on the duration and frequency of diarrhea and on the volume and consistency of stools in children with acute diarrhea [Paediatr Indones 2005;45:65-68]
\end{abstract}

Keywords: fructooligosaccharide, prebiotic, acute diarrhea, mild dehydration, moderate dehydration
$\mathrm{D}$ iarrhea is a cause of significant morbidity and mortality in childhood. In developing countries, 1.3 billion episodes of diarrhea and 3.2 million deaths due to this disease occur every year. In a study held in 8 provinces by the Indonesian Ministry of Health, morbidity caused by diarrhea in 1989, 1990 and 1995 were $78.5 \%, 103 \%$, and 100\%, respectively. ${ }^{1}$ Diarrhea may lead to a state of dehydration through body fluid and electrolyte loss, potentially fatal if prompt and proper treatment were not obtained. The World Health Organization's protocol of diarrhea management covered methods of examination and treatment. Examination of the patient with diarrhea involves body weight measurement and determination of the degree of dehydration, whereas treatment involves fluid and electrolyte correction, diet, and drug therapy. ${ }^{2}$

Prebiotic agents have been suggested as supplemental therapy aimed to speed up diarrhea remission. However, only few studies have focused on the use of prebiotics in the treatment of diarrhea. This study attempts to investigate the efficacy of fructooligosaccharide (FOS), a prebiotic agent, in the management of acute diarrhea.

From the Department of Child Health, Medical School, University of Sumatera Utara, Medan, Indonesia.

Reprint requests to: Reni Suryanty, MD, Department of Child Health, Medical School, University of Sumatera Utara, Adam Malik Hospital, Jl. Bunga Lau No.17, Medan, Indonesia. Tel/Fax. 62-21-8361721. 
Methods

This double-blind randomized clinical trial was carried out from July to November 2003 in the pediatric intensive care unit, polyclinic, and pediatric ward of Adam Malik Hospital and Pirngadi Hospital, Medan. The patient population consisted of children and infants aged 4 to 24 months suffering from acute diarrhea without dehydration or with mild to moderate dehydration. This study was approved by the Medical Ethics Committees of Adam Malik Hospital and Pirngadi Hospital, Medan.

Patients were included in this study if they were 4 to 24 months old, suffered from acute diarrhea without dehydration or with mild to moderate dehydration and did not have any severe underlying disease such as bronchopneumonia or encephalitis. Written parental informed consent had to be obtained for all subjects. Patients were excluded if they, during the period of study, developed a severe disease such as bronchopneumonia or encephalitis or were diagnosed with severe malnutrition according to CDC NCHS 2000 standards.

Using a randomization table, each patient was randomly assigned to receive tablets containing either $600 \mathrm{mg}$ FOS or $761 \mathrm{mg}$ fructulin as placebo. Examiners and parents were blinded to the contents of the tablets. Both FOS and placebo tablets were identical in shape, color, and flavor. Tablets were administered orally by a parent, twice daily for 5 days.

Rehydration according to WHO protocol was performed on patients with dehydration. Body weight and temperature were measured prior to administration of the tablets. Body weight, temperature, and the frequency, volume, and consistency of stools were recorded daily. Home visits were performed for outpatients.

Difference in stool consistency was analyzed using the chi-square test, and diarrhea duration, its frequency, and stool volume using the independent $t$ test. Multivariate analysis was performed to determine the effect of treatment on all the above variables. The difference was considered statistically significant if $\mathrm{P}<0.05$. Data were analyzed using SPSS 10.0 for Windows.

\section{Results}

Out of 142 patients who fulfilled inclusion criteria, only 135 completed the study. Seven patients dropped out, 3 from the FOS group and 4 from the placebo group. Subject characteristics with respect to age, birth weight, nutritional status, duration of diarrhea at home, and breastfeeding status, were similar in both groups at the start of the study. However, sex distribution between the two groups was not similar (Table 1).

TABle 1. Subject Characteristics

\begin{tabular}{|c|c|c|}
\hline \multirow[b]{2}{*}{ Characteristic } & \multicolumn{2}{|c|}{$\mathbf{N}$} \\
\hline & $\begin{array}{l}\text { FOS } \\
(n=68)\end{array}$ & $\begin{array}{l}\text { Placebo } \\
(n=67)\end{array}$ \\
\hline \multicolumn{3}{|l|}{ Age } \\
\hline$<12$ months & $35(51.47 \%)$ & $42(62.69 \%)$ \\
\hline$\geq 12$ months & $33(48.53 \%)$ & $25(37.3 \%)$ \\
\hline \multicolumn{3}{|l|}{ Sex } \\
\hline Male & $33(48.53 \%)$ & $45(67.16 \%)$ \\
\hline Female & $35(51.47 \%)$ & $22(32.84 \%)$ \\
\hline \multicolumn{3}{|l|}{ Body weight } \\
\hline mean $\pm \mathrm{SD}(\mathrm{kg})$ & $15.89 \pm 1.93$ & $9.67 \pm 1.18$ \\
\hline \multicolumn{3}{|l|}{ Nutritional status } \\
\hline Normal & $25(36.76 \%)$ & $19(28.36 \%)$ \\
\hline Mild malnutrition & $18(26.47 \%)$ & $27(40.30 \%)$ \\
\hline Moderate malnutrition & $25(36.76 \%)$ & $21(31.34 \%)$ \\
\hline \multicolumn{3}{|l|}{ Diarrhea duration at home } \\
\hline mean \pm SD $(\mathrm{kg})$ & $2.65 \pm 1.50$ & $2.79 \pm 1.23$ \\
\hline \multicolumn{3}{|l|}{ Breastfeeding } \\
\hline Breastfed & $42(61.76 \%)$ & $48(71.64 \%)$ \\
\hline Not breastfed & $26(38.24 \%)$ & $19(28.36 \%)$ \\
\hline
\end{tabular}

At the end of the study, no significant difference was found in nutritional status and duration of diarrhea of both groups $(\mathrm{P}>0.05)$. Throughout the five days of observation, a significant difference was found neither in the stool consistency $(\mathrm{P}>0.05)$ nor volume ( $\mathrm{P}>0.05)$ (Tables 2 and 3). However, mean stool volume in the FOS group showed a decreasing trend during the second to fourth days of observation (Table 3).

On the first 3 days of observation, there was no significant difference in diarrhea frequency of both groups $(\mathrm{P}>0.05)$. In the $4^{\text {th }}$ and $5^{\text {th }}$ days of observation this difference became significant $(\mathrm{P}=0.017$ and 0.025 for the $4^{\text {th }}$ and $5^{\text {th }}$ days, respectively) (Table 3 ). However, when multivariate analysis controlled for sex group was performed, FOS treatment was found to have no effect on the duration and frequency of diarrhea, stool volume, and stool consistency. 
Reni Suryanty et al: Efficacy of fructooligosaccharide for treatment of acute diarrhea in children

Table 2. Stool Consistency, observed IN THE $1^{\text {ST }}-5^{\text {TH }}$ DAY

\begin{tabular}{|c|c|c|c|c|c|c|c|}
\hline \multirow{2}{*}{$\begin{array}{l}\text { Day of } \\
\text { observation }\end{array}$} & \multicolumn{2}{|c|}{ Liquid (\%) } & \multicolumn{2}{|c|}{ Semi Solid (\%) } & \multicolumn{2}{|c|}{$\begin{array}{c}\text { Solid (\%) } \\
\end{array}$} & \multirow[t]{2}{*}{$\mathbf{P}$} \\
\hline & FOS & Placebo & FOS & Placebo & FOS & Placebo & \\
\hline $1^{\text {st }}$ & 34 (51.5) & $32(48.5)$ & 28 (47.5) & $31(52.5)$ & $1(50.0)$ & $1(50.0)$ & 0.902 \\
\hline $2^{\text {nd }}$ & $13(56.5)$ & $10(43.5)$ & $30(52.6)$ & $27(47.4)$ & $9(40.9)$ & $13(59.1)$ & 0.537 \\
\hline $3^{\text {rd }}$ & $7(70.0)$ & $3(30.0)$ & $12(48.0)$ & $13(52.0)$ & $18(52.9)$ & $16(47.1)$ & 0.496 \\
\hline $4^{\text {th }}$ & $4(100.0)$ & $0(0.0)$ & $5(55.6)$ & $4(44.4)$ & $10(62.5)$ & $6(37.5)$ & 0.277 \\
\hline $5^{\text {th }}$ & $1(100.0)$ & $0(0.0)$ & $6(100.0)$ & $0(0.0)$ & $4(66.7)$ & $2(33.3)$ & 0.252 \\
\hline
\end{tabular}

Table 3. Stool Volume and fRequency of DiarRhea, observed IN THE $1^{\mathrm{ST}}-5^{\mathrm{TH}}$ DAY

\begin{tabular}{|c|c|c|c|c|c|}
\hline \multirow{3}{*}{ Day of observation } & \multicolumn{5}{|c|}{ Stool Volume } \\
\hline & \multicolumn{2}{|c|}{$\mathbf{N}$} & \multicolumn{2}{|c|}{ Mean (SD) } & \multirow[t]{2}{*}{$\mathbf{P}$} \\
\hline & FOS & Placebo & FOS & Placebo & \\
\hline $1^{\text {st }}$ & 57 & 60 & $67.37(27.82)$ & $60.55(26.06)$ & 0.174 \\
\hline $2^{\text {nd }}$ & 43 & 35 & $52.67(3.99)$ & $55.57(23.63)$ & 0.569 \\
\hline $3^{\text {rd }}$ & 21 & 14 & $45.71(3.21)$ & $46.07(21.05)$ & 0.893 \\
\hline $4^{\text {th }}$ & 11 & 4 & 44.09 (7.95) & $43.75(7.12)$ & 0.942 \\
\hline $5^{\text {th }}$ & 8 & 1 & $38.13(7.35)$ & $45.00(9.46)$ & 0.487 \\
\hline \multicolumn{6}{|c|}{ Frequency of Diarrhea } \\
\hline $1^{\text {st }}$ & 68 & 67 & $5.81(3.45)$ & $4.81(3.07)$ & 0.077 \\
\hline $2^{\text {nd }}$ & 68 & 67 & $3.40(2.98)$ & $2.87(2.93)$ & 0.299 \\
\hline $3^{\text {rd }}$ & 68 & 67 & $1.74(2.51)$ & $1.06(1.62)$ & 0.66 \\
\hline $4^{\text {th }}$ & 68 & 67 & $0.91(2.03)$ & $0.27(0.79)$ & ${ }^{*} 0.017$ \\
\hline $5^{\text {th }}$ & 68 & 67 & $0.41(1.10)$ & $0.007(0.50)$ & ${ }^{*} 0.025$ \\
\hline
\end{tabular}

\section{Discussion}

In this study, there were more male $(57.7 \%)$ than female subjects. This implies that the incidence of acute diarrhea may be different between the two sexes. Diarrhea was more prevalent in the age group of $<12$ months $(57 \%)$. This finding is consistent with that of a previous study by Marbun et al in the same region, which found that diarrhea occurred most frequently in the first 2 years of life, with the highest incidence in the 6-11 month age group. ${ }^{3}$ Malnourished children tend to be more susceptible to gastrointestinal infection, diarrhea, and endotoxemia, due to an impaired immunological system and structural changes of the intestinal mucosa. These changes have been said to extend the duration of diarrhea. ${ }^{4}$ The addition of FOS in the management of malnourished diarrhea patients may shorten the duration of their illness. There was no significant difference in the volume and consistency of stools and frequency of diarrhea in the placebo and FOS groups, but in the second to fifth days of treatment the stool volume of patients receiving FOS tends to decrease. In a double-blind, controlled trial by Haschke et al, in which FOS was given as a supplement in cereal, no significant difference between the two groups was found in the frequency of diarrhea, but symptoms such as fever, vomiting, and abdominal cramps were significantly decreased in the FOS group. ${ }^{5}$ McFarlane et al noted that administration of 2.5, 5, and $10 \mathrm{~g}$ of galactoligosaccharide increased faeces bifidobacteria secretion although there was no change in stool volume and frequency of diarrhea. ${ }^{6}$ In another study by Juffrie et al, the group receiving FOS had shorter diarrhea duration than the control group.

We conclude that giving FOS as a supplemental therapy on acute diarrhea has no effect on diarrhea duration and frequency nor on stool volume and consistency. 


\section{Paediatrica Indonesiana}

\section{References}

1. Direktorat Jenderal PPM \& PLP. Epidemiologi dan etiologi diare. In: Pendidikan Medik Pemberantasan Diare (PMPD). Jakarta: Departemen Kesehatan RI; 1999. p. 3-32.

2. Sinuhaji AB. Patofisiologi dan tatalaksana diare akut pada neonatus dan bayi. In: Pasaribu S, Lubis M, Lubis B, editors. Penatalaksanaan diare pada bayi dan neonatus. Medan: Fakultas Kedokteran Universitas Sumatera Utara; 1999. p. 1-8

3. Marbun MD, Sinuhaji AB, Sebayang T, Daulay RM, Sutanto AH. Gambaran penderita gastroenteritis di bagian Ilmu Kedokteran Anak RS Dr. Pirngadi Medan tahun 1982. Medika 1987;11:1065-77.

4. Lifshitz F. Interrelationship of diarrhea and infant nutrition. In: Labenthal E, editor. Textbook of gastroenterology and nutrition in infancy. $2^{\text {nd }}$ edition. New York: Raven Press; 1989. p. 657-63.

5. Haschke F, Firmansyah A, Meng M, Steenhouth, Carrie AL. Functional food for infants and children. Monatsschr Kinderheilkd 2001;149(suppl 1):66-70.

6. MacFarlane GT, Cummings JH. Probiotics and prebiotics: can regulating the activates of intestinal bacteria benefit health? BMJ 1999;318:999-1003.

7. Juffrie M. Fructooligosaccharide and diarrhea. Biosci Microflora 2002;21:31-4. 